\section{The increase of fibroblast cells number in rat (rattus norvegicus) gingival wound after the application of moringa (moringa oleifera lam) fruit oil}

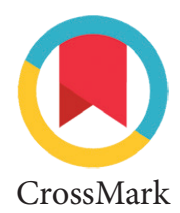

\author{
Asmawati, ${ }^{1 *}$ Bahruddin Thalib, ${ }^{2}$ Nurhayaty Natsir, ${ }^{3}$ Alqarama M. Thalib, ${ }^{4}$ \\ Rafikah Hasyim ${ }^{1}$
}

\title{
Abstract
}

Objective: To determine the increase of fibroblast cell number in the rat (Rattus norvegicus) gingival wound after the application of moringa (Moringa oleifera Lam) fruit oil.

Material and Methods: This study was an experimental post-test control group design using 18 male Wistar rats (Rattus norvegicus) that was divided into three groups. The sample was previously incised with a length of $4 \mathrm{~mm}$ using scalpel 15 . Group 1 was applied with moringa fruit oil, group 2 was given aspirin, and group 3 was given at $0.5 \%$ CMC. The application was carried out every 24 hours, then on the third and seventh day, the rats were euthanized for histological preparations and then observed under the electric microscope. The length of the lesion was measured on the first, third, and seventh days. The fibroblast was then observed by counting the number of fibroblast cells per field of view using an Olympus (-21 microscope with an Optilab Advances camera with a 40x, 100x magnification, and 400x. The data were processed and analyzed using the SPSS Version 21 program. This study used a t-test to see the differences between the treatment group and the control group, and the Least Significantly Difference (LSD) test was used to see the size of the difference.

Results: This study showed a significant increase in the number of fibroblasts in rat gingival mucosa on the third and seventh days.

Conclusion: Moringa (Moringa oleifera Lam) fruit oil affects increasing the number of fibroblasts on the rat gingival mucosa (Rattus norvegicus).

Keywords: Cholagenic, Moringa fruit (Moringa oleifera Lam), Rat gingival wound

Cite this Article: Asmawati, Thalib B, Natsir N, Thalib AM, Hasyim R. 2020. The increase of fibroblast cells number in rat (rattus norvegicus) gingival wound after the application of moringa (moringa oleifera lam) fruit oil. Journal of Dentomaxillofacial Science 5(3): 173-176. D01: 10.15562/ jdmfs.v5i3.1121

'Department of Oral Biology, Faculty of Dentistry, Hasanuddin University, Makassar, Indonesia ${ }^{2}$ Department of Prosthodontics, Faculty of Dentistry, Hasanuddin University, Makassar, Indonesia ${ }^{3}$ Department of Conservative Dentistry, Faculty of Dentistry, Hasanuddin University, Makassar, Indonesia ${ }^{4}$ Department of Dental Material, Faculty of Dentistry, Hasanuddin University, Makassar, Indonesia

*Correspondence to: Asmawati, Department of Oral Biology, Faculty of Dentistry, Hasanuddin University, Makassar, Indonesia asmaamin281068@gmail.com

Received: 12 April 2020

Revised: 10 June 2020

Accepted: 9 August 2020 Available

Online: 1 December 2020

\section{Introduction}

Ulcers are lesions that damage the epithelium beyond the basal membrane with a clear border that can cause injury. The most common oral disease is recurrent aphthous stomatitis and a traumatic ulcer of the gingiva. Moringa Oleifera Lamk fruit seeds contain flavonoids, saponins, tannins, alkaloids, vitamins $\mathrm{A}, \mathrm{B} 1, \mathrm{~B} 2$, and $\mathrm{C}$ and have pharmacological effects anti-inflammatory, anti-pyretic, and antiscorbutic. ${ }^{1}$

According to Fuadi, in 2015, moringa plants have anti-inflammatory properties, with flavonoid and tannin compounds that work by stimulating cells such as macrophages to produce growth factors and cytokines such as EGF, TGF- $\beta$, IL-1, IL-4, IL-8. TGF- $\beta$ and EGF function to induce proliferation and migration of fibroblasts and the induction of fibroblasts in the extracellular matrix production. IL-1, IL-4, and IL-8 function to induce chemotaxis of fibroblasts and keratinocytes, activating fibroblast proliferation. ${ }^{2,3}$ Thus, the authors were interested in studying the increased fibroblast number on rat gingival wound after the application of moringa fruit seed.

\section{Material and Methods}

\section{Preparation of Moringa fruit seed extract}

Moringa fruit seed extract is an extracted material in oil form obtained from the manufacturer of pure Moringa fruit seed extract that has been certified.

\section{Preparation of research animals}

Eighteen healthy male Wistar rats with 250 grams of body weight and age 3 months old were divided into 3 groups.

\section{Preparation of Control Material}

The aspirin dose of $360 \mathrm{mg} / \mathrm{kg}$ body weight of mice was used as a positive control adjusted for the dose conversion of aspirin as an anti-inflammatory in humans, which is 4 grams per day. The aspirin solution is made by dissolving $18 \mathrm{mg}$ aspirin $1 \mathrm{ml}$ of $0.5 \%$ CMC Na with a mortal-pastel help. CMC $\mathrm{Na} 50 \mathrm{gr}$ is dissolved in sterile distilled water till it reached $100 \mathrm{ml}$.

This study was an experimental laboratory with a post-test control group design using 18 wistar strains (rattus norvegicus) as a sample that 

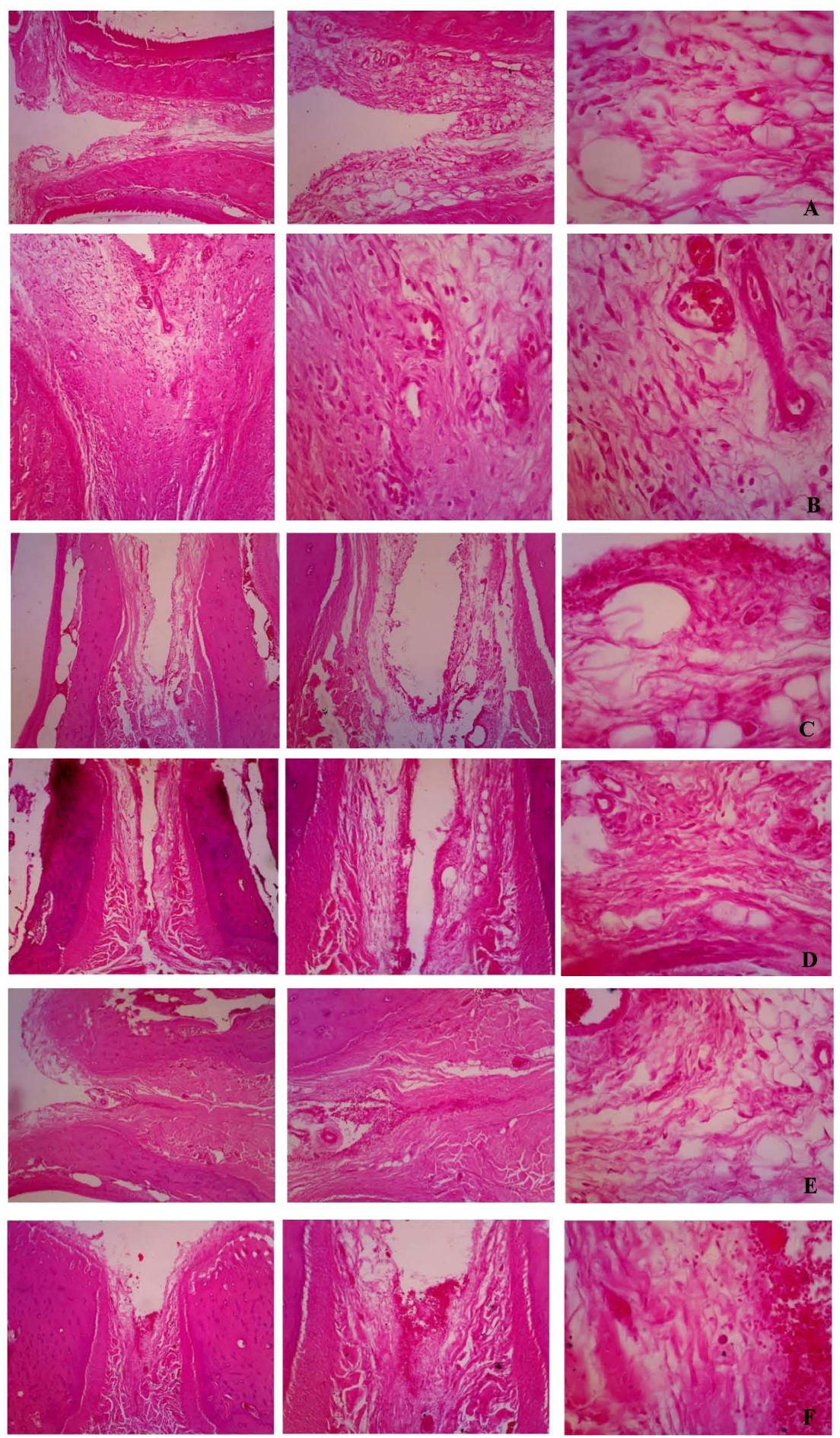

Figure 1 A. Histology features of aspirin group on day 3 with magnification 40x, 100x, and 400x, B. Histology features of Aspirin group on day 7 , with magnification 40x, 100x, and 400x, C. Histology features of Moringa fruit seed oil group on day 3 with magnification 40x, 100x, and 400x, D. Histology features of Moringa fruit seed oil group on day 7 with magnification 40x, 100x, and 400x, E. Histology features of CMC group on day 3 with magnification 40x, 100x, and 400x,

F. Histology features of CMC on day 7 with magnification 40x, $100 x$, and 400 previously made an incision on the anterior lower mandible with a length of $4 \mathrm{~mm}$ using scalpel No.15, then divided into 3 groups. The first group was applied with Moringa fruit seed extract using a sterile swab, the second group was given aspirin application, and the third group was given a $0.5 \%$ CMC application. The application was carried out every 6 hours then on the third and seventh day figure $1 \mathrm{~A}$ - figure 1D. The rats were euthanized by anesthesia and cervical dislocation to make histological preparations where the tissue was taken as large as the wound then fixed with $10 \% \mathrm{NBF}$ solution for 24 hours then the tissue was cut and inserted into the specimen container plastic pots called cassettes then dehydrated by soaking it into $70 \%, 80 \%$ and $90 \%$ alcohol, absolute alcohol one and absolute alcohol 2. Purification and infiltration were done with xylol.

After printed in paraffin blocks and stored in the refrigerator, the paraffin block was cut with a microtome with a slice thickness of 5-6 $\mu \mathrm{m}$, floated in the water with temperature $60^{\circ} \mathrm{c}$ to avoid the folds of the preparation, and then lifted and placed on the glass object to perform hematoxylin and eosin (HE) staining. The fibroblast was then observed by counting the number of fibroblast cells per field of view using an olympus C-21 microscope with an optilab Advances camera with a 40x, 100x magnification, and 400x figure $1 \mathrm{E}$ and figure $1 \mathrm{~F}$.

\section{Results}

After making preparation and staining with HE, the observation is then carried out under a microscope. Observation of collagen thickness was carried out using an Olympus C-21 microscope with an Optilab Advances camera with 40X magnification, 400X.

\section{Fibroblast cells}

Table 1 shows the counting of fibroblasts cell number per field of view on the treatment group. The mean was 80.67 on day 3 and 125.33 on day 7 .

Table 2 shows the fibroblast cell number per field of view in the positive control group (Aspirin group). The mean was 46.67 on day 3 and 105.33 on day 7.

Table 3 shows the fibroblast cell number per field of view in the negative control group (CMC). The mean was 29.67 on day 3 and 50 on day 7 .

Table 4 shows the analysis of the increased fibroblast cells number in CMC Na 0.5\%, aspirin, and moringa fruit seed oil against the fibroblast cells number of male Wistar rat gingival mucosa on day 3. 
Table 1 The fibroblast cells number on day three and day $\mathbf{7}$ in the Moringa fruit seed oil group

\begin{tabular}{lcc}
\hline Moringa fruit seed oil group & Day 3 & Day 7 \\
\hline Moringa fruit seed oil 1 & 82 & 105 \\
Moringa fruit seed oil 2 & 80 & 141 \\
Moringa fruit seed oil 3 & 80 & 130 \\
Mean & 80.66667 & 125.3333 \\
\hline
\end{tabular}

Table 2 The fibroblast cells number on day three and day $\mathbf{7}$ in the Aspirin group

\begin{tabular}{lcc}
\hline Aspirin group & Day 3 & \\
\hline \multirow{2}{*}{ Aspirin 1 } & & Day 7 \\
& 65 & 99 \\
Aspirin 2 & 30 & 116 \\
\hline Aspirin 3 & 45 & 101 \\
& 46.66667 & 105.3333 \\
\hline
\end{tabular}

\begin{tabular}{ll}
\hline Table 3 & $\begin{array}{l}\text { The fibroblast cells number on day } 3 \text { and day } 7 \text { in the CMC } \\
\text { group }\end{array}$
\end{tabular}

CMC group

Day 3 Day 7

$\underline{\mathrm{CMC}} 1$

28

CMC 2

30

\begin{tabular}{llcc}
\hline CMC 3 & & Fibroblast(Mean \pm SD) & P \\
\hline CMC Na 0.5\% & 3 & $29.67 \pm 1.53$ & \\
Aspirin & 3 & $46.67 \pm 17.56$ & 0.002 \\
$\begin{array}{l}\text { Moringa fruit seed } \\
\text { oil }\end{array}$ & 3 & $80.67 \pm 1.15$ & \\
\hline
\end{tabular}

One Way Anova $(\mathrm{p}<0.05)$

Table 5 The analysis of fibroblast cells number in the three groups on day 7

\begin{tabular}{llcc}
\hline Group & $\mathbf{n}$ & Fibroblast (Mean \pm SD) & P \\
\hline CMC Na 0,5\% & 3 & $50.0 \pm 2.00$ & \\
Aspirin & 3 & $105.33 \pm 9.29$ & 0.001 \\
$\begin{array}{l}\text { Moringa fruit seed } \\
\text { oil }\end{array}$ & 3 & $125.33 \pm 18.45$ & \\
\hline
\end{tabular}

One Way Anova $(\mathrm{p}<0.05)$ number of male Wistar rat gingival mucosa on day 7.

The one-way ANOVA test shows a significant increase of $0.001 \quad(p<0.05)$, which shows the significant difference of fibroblast cell number in each group.

\section{Discussion}

The oral lesion can result from physical, thermal, or chemical injuries. The most common causes of mechanical injury are denture irritation, bite trauma, burning and frictional irritation from sharp or fractured teeth, and teeth malposition. Other causes such as grinding your teeth at night (nocturnal clenching) or biting your lips and tongue, thermal and electrical sores, and hot food and drink can also cause oral lesions. ${ }^{3,4}$

Other wounds that are more severe and deep are extraction wounds, wounds after molar surgery, and wounds after removing tumors or abnormalities of the oral cavity. The wound is usually oval and painful, confined to the affected area. Ulcers may appear as yellowish-white necrotic areas surrounded by large erythematous areas. They are generally about 1 $\mathrm{cm}$ in size and can heal spontaneously over 10-14 days, leaving no scars. ${ }^{2,5}$

The tannins in moringa seed oil have cellular mechanism activity, such as cleaning free radicals and reactive oxygen, increasing wound connection, and increasing capillary formation and activation of fibroblasts. ${ }^{6}$

Saponins are also one of the compounds that stimulate fibroblasts and collagen, which play a role in the wound healing process. Saponins also have cleansing abilities, so they are effective in healing open wounds. Saponins can increase the permeability of bacterial cell membranes so that they can change the membrane's structure and function, cause denaturation of membrane proteins so that the cell membrane will be damaged and lysis, and cause bacterial destruction. ${ }^{5,7}$

The role of fibroblasts is very important in the repair process, which is responsible for producing protein structure products that will be used during the tissue reconstruction process. In normal circumstances, fibroblast division activity is rarely seen, but when there is injury, these cells appear to be more active in producing the extracellular matrix. Fibroblast proliferation in the process of wound healing is naturally stimulated by interleukin-Ib (ILIb), platelet-derived growth factor (PDGF), and fibroblast growth factor (FGF). The wound healing process is strongly influenced by 
Fibroblasts play a role in the wound healing process in the proliferation stage. The epithelialization process occurs. After the wound's occurrence, there are morphological changes in keratinocytes at the wound edges. In the injured skin, the epidermis thickens, and the marginal basal cells expand and migrate to meet the defects in the wound. Then followed by the fibroplasia process, which is a process of fibroblast proliferation, migration of fibrin clots to the wound area, and the production of new collagen and other protein matrices involved in the formation of granulation tissue. .,6,8 $^{4}$

The visible result of the wound healing process is the formation of scar tissue. The morphology of scar tissue is formed due to the lack of tissue structure compared to the surrounding normal tissue arrangement. ${ }^{3}$

\section{Conclusion}

Moringa fruit seed (Moringa oleifera Lam) affects the increased fibroblast number in male Wistar rat (Rattus norvegicus) gingival mucosa. There was a significant increase in fibroblast numbers after the application of moringa fruit seed oil.

\section{Acknowledgment}

None.

\section{Conflict of Interest}

The authors report no conflict of interest.

\section{References}

1. Krisnadi AD. Super nutritional moringa. Medan: Kunduran Blora; 2015. p. 8-17. (In Indonesia)

2. Ma'ruf A, Supriadi, Nuryanti S. Utilization of moringa oleifera L. seeds as toothpaste. J Akad Kim 2016;5: 61-66. (In Indonesia)

3. Nuryanti S, Mustapa K, Sudarmo IG. Inhibition test of moringa (moringa oleifera lamk) fruit extract against candida albicans fungus growth. J Akad Kim 2016;5: 178-184. (In Indonesia)

4. Fuadi MI, Elfiah U, Misnawi. The number of fibroblasts in second degree burns in rats by administering ethanol extract gel of cocoa beans and silver sulfadiazine. J Pustaka Kesehatan 2015;3: 244-248. (In Indonesia)

5. Cavalcante GM, Paula RJS de, Souza LP de, et al. Experimental model of traumatic ulcer in the cheek mucosa of rats. Acta Cir Bras 2011;26: 227-234.

6. Palumpun EF, Wiraguna AAGP, Pangkahila W. Topical administration of betel leaf extract (Piper betle) increased the thickness of the epidermis, the number of fibroblasts, and the amount of collagen in the wound healing process in male Wistar rats (Rattus norvegicus). J EBiomedikeBm. 2017;5: 1-7. (In Indonesia)

7. Parampasi N, Soemarno T. The effect of giving papaya leaf extract in $70 \%$ ethanol on the healing process of the incision wound. Maj Patol 2013;22: 31-36. (In Indonesia)

8. Siswanto A, Dewi N, Hayatie L. Effect of haruan (channa striata)extract on fibroblast cells count in wound healing. J Dentomaxillofac Sci 2016;1: 89-94.

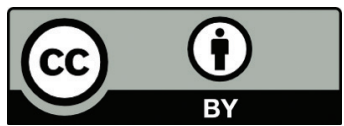

This work is licensed under a Creative Commons Attribution 